\title{
The importance of organizational climate for management development
}

\author{
I.H. Nurick \\ Professional and Computer Services, Johannesburg
}

The article records the opinions of nine South African managers in the personnel and training fields regarding the importance of organizational climate for management development, and relates these to some relevant theory. The author examines what management development is, why corporations invest in management development programmes, and who is responsible for this task. He then discusses the relationship between management development and organizational climate, and shows how a poorly implemented management development programme can adversely affect organizational climate. Factors considered include: top-management commitment, management style, attitude towards delegation, insecurity and resistance to change, counselling and coaching, profit orientation, organizational pressures, and incentive for development. The practical experience and opinions of the managers interviewed enhance and illustrate the points discussed

S. Afr. J. Bus. Mgmt. 1981, 12: 115-121

Die artikel gee 'n opsomming van die menings van nege SuidAfrikaanse bestuurders in die personeel- en opleidingsgebiede aangaande die belangrikheid van organisasieklimaat in bestuursontwikkeling en bring dit in verband met toepaslike teorie. Die outeur ontleed bestuursontwikkeling, waarom maatskappye daarin belê, en wie vir hierdie taak verantwoordelik is. Hy bespreek daarna die verhouding tussen bestuursontwikkeling en organisasieklimaat en dui aan hoe 'n swakgeïmplementeerde bestuursontwikkelingsprogram organisasieklimaat nadelig kan beïnvloed. Faktore wat oorweeg word, sluit in: ondersteuning van topbestuur vir die projek, bestuurstyl, houding teenoor delegasie, insekuriteit en weerstand teen verandering, voorligting en onderrig, winsorièntasie, organisasiedruk en aansporing tot ontwikkeling. Die praktiese ervaring en menings van bestuurders met wie onderhoude gevoer is, belig en illustreer die punte wat bespreek word.

S.-Afr. Tydskr. Bedryfs/. 1981, 12: 115-121

First published as a 'Business Alert' paper, by the Graduate School of Business Administration of the University of the Witwaterstand

I.H. Nurick

Professional and Computer Services, P.O. Box 17105, Hillbrow 2038, RSA

Received July 1981; accepted August 1981

\section{Introduction}

The objective of this article is not that it should become a theoretical exposition of the importance of organizational climate for management development, but rather to record the opinions and experiences of nine people interviewed who are employed in large and small corporations, both local and multinational, operating in South Africa, on the subject of management development. The opinions expressed are those of the author and the persons interviewed and not of the organizations to which they belong.

In order to obtain a full perspective on the subject under discussion, it is necessary first to examine what management development is; why corporations today see fit to invest in management development programmes; and finally to consider and debate upon the question of, on whom the basic responsibility for management development falls - the company represented by its management, or the employee.

The term management development will, throughout this article, refer to both supervisory and middle management. In addition, use of the male gender will be taken to include females as well.

\section{What is management development?}

De Bettignies' defines management development as 'the attempt to improve managerial effectiveness through a planned and deliberate learning process'. It is a social influence of change, which deals with a change of attitudes, skills and knowledge, all of which affect managerial behaviour, job performance, and finally return on investment. Management development involves sound selection procedures, organization and manpower planning, performance evaluations, reviews and appraisals, and dayto-day coaching and counselling. It also involves planned learning experiences including courses, seminars, workshops and individual reading programmes. Most importantly, it involves individual desire and commitment. ${ }^{2}$ However, Drucker ${ }^{3}$ submits that management development cannot succeed if its aim is to alter dramatically personalities or values or beliefs. The focus of development and educational activities must be on the individual's worth rather than on personality. 


\section{Why management development?}

Business enterprises in the early part of this century operated in a rather static and predictable environment, characterized by several factors, some of which are:

- the market comprised many small businesses, none of whom could, through their own actions, influence the market for their product(s);

- a low level of product differentiation was common;

- the consumer tended to be unsophisticated and rather predictable in his buying behaviour;

- the balance of power was biased in favour of the employer who in the main, ran his business in a controlled, autocratic and unsophisticated manner.

Many and varied interacting factors have precipitated changes in the environment with the effluxion of time. Today, a business must be flexible and capable of meeting the challenges of change. Some of the more pertinent changes which are making a significant impact on managers today include:

- Technological changes, which may necessitate changes in organization structure, strategy, and management styles and practices.

- Changes in public attitudes and demands, which are creating the 'public-oriented' manager. ${ }^{4}$

- Changes in economic, competitive, legal and consumer environments.

- Changes in employees' values, lifestyles and educational levels which call for different ways of leading and motivating employees. ${ }^{2}$

- Changes in population: increasing numbers of people, shifts in age distribution, rising education and affluence levels, all of which call for dramatic changes in organization and methods of managing.

In addition, Watson ${ }^{2}$ suggests that as the employee climbs the organizational ladder, the scope of responsibility widens beyond the supervisor's or manager's specific technical ability. He states that 'unfortunately, success in handling technical assignments is no guarantee of success in handling managerial assignments'. Furthermore, the transition from 'doing' to 'managing' is a difficult process.

Management development, therefore, seeks to assist the company in coping with a dynamic and constantly changing environment by 'continuously generating a pool of professional managers in all functions and at all levels'.6

\section{Upon whom does the responsibility for manage- ment development fall?}

Gibson 7 believes that the responsibility for management development primarily rests with the company. This is because the company develops people who will assist in achieving its stated objectives, with the individual's objectives being of secondary importance.

This is in direct conflict with Woodhouse, who submits, quoting Professor Tom Mahoney, that 'all development is self-development', that it is the employee's responsibility to develop his skills and attitudes, to increase his knowledge, to improve his present performance and potential for progress. The company's role is to monitor and discuss progress and to provide suggestions and facilities and sometimes finance.

Bacchioni ${ }^{9}$, on the other hand, propagates a more conservative viewpoint - that the responsibility for management development is a shared one. He states that the personnel function should:

- indicate the training courses available (including attitudinal courses); and

- provide opportunities for travel and outside study.

Line management, on the other hand, should provide:

- efficient and effective on-the-job training; and

- opportunities for the individual to develop.

The individual in turn must:

- indicate what his career aspirations are;

- how he intends achieving those aspirations, and finally, do something constructive towards their achievement.

Like Bacchioni, Sewell ${ }^{6}$ believes that the responsibility for management development is a shared one. He believes that management development is the joint responsibility of line management and human resources specialists who create the climate to facilitate development. The actual development must, however, be motivated by the employee himself. Specifically, line management must clarify corporate aims and regularly review career directions; they must identify talent and assess readiness for promotion; they should exploit operational tasks as opportunities to develop skills and reduce weaknesses; and finally, they must coach performance supportively.

The human resource specialists fulfil their role by planning numbers and directions of career paths that will satisfy both operational and strategic needs, motivating the system, stimulating action with constructive advice, and monitoring organizational and managerial wellbeing, recommending corrective action where applicable. The human resource specialist, must, in addition, teach each member of staff how to manage his own personal growth by explicitly identifying career ambitions and goals, preparing a profile of personal strengths and weaknesses, and preparing a skills inventory. In so doing, it is possible to obtain goal congruency between the individual and the corporation. This is essential if the management development system is to be optimized.

In his article 'Top Management's Role in Management Development', Krieken ${ }^{10}$ states that because management development is concerned with developing managerial ability in all functions, at all levels, and in all departments of the organization, it is first and foremost the responsibility of top management who must:

- create the climate, structure and procedures which foster development of people in and for managerial functions. This is a permanent condition, primarily a line management responsibility at every level;

- periodically make appraisals of present and future management talent, in both quantity and quality; and

- organize both internal and external programmes to accelerate, but not replace, the autonomous natural management development within the organization. 
This is mostly a staff management function.

\section{What is organizational climate?}

Every organization employs people who interact on a daily basis directing their efforts towards the achievement of the organization's goals and hopefully, their own. At the one end of the continuum are people who work because they are forced to, and who are motivated by the cheque they receive at the end of each month. At the other end of the scale, there are those career-oriented people, who seek challenge and stimulation from their jobs and who aspire to more senior positions. It is generally this category of person that any management development system will best serve. The organizational climate is formed by these individuals, each of whom has his own value and belief system.

Horner" aptly describes organizational climate as a psychological contract between the company (who is represented by its managers) and their subordinates. This psychological contract is the understanding in the subordinate's mind of the degree of his subordination to the company and its needs. The concept in the subordinate's mind of the degree of authority and initiative he has would best describe the type of climate that exists within that company.

According to Hellriegel and Slocum ${ }^{12}$ there are basically three different types of organizational climate power, affiliation, and achievement. A power-motivated organizational climate is characterized by autocratic management styles, centralized decision-making, rigid rules and procedures, and clearly defined lines of communication. An organization which emphasizes warm working relations more than achievement of results, is called the affiliation-oriented organization. While formal management development policies and programmes might be prescribed in both types of organizations just described, their effectiveness in practice would generally be questionable. This statement will be satisfactorily demonstrated in the discussion which follows. Generally, positive results from management development efforts are found in the achievement-oriented organization which can best be described as one in which top management formulates objectives in collaboration with other managers, permitting them to establish their own procedures for achieving these objectives, and rewarding employees on the basis of their actual performance. In the achievement organization, managers continually communicate a high-performance expectation to employees and top management are seen to be genuinely interested in providing employees with opportunities for career advancement.

\section{Organizational climate and management develop- ment}

Organizational climate and management development interrelate one with the other. Generally, organizational climate is the more dominant of the two factors. However, it will be shown that a poorly implemented management development programme can have a detrimental effect upon the organization's climate.

This interrelationship is well illustrated by Kellog ${ }^{5}$ who suggests that there are three factors which are continuously involved: (i) The employee himself - his abilities, knowledge and skill; his attitudes, interests, values and career aspirations.

(ii) The work for which the employee is responsible or which is asked of him - its demands for new knowledge and skill or for changes in attitudes, interests and values.

(iii) The climate, situation or environment in which the work is undertaken, including the manager's style of managing, his attitudes and interests, the pressures on the organization, the facilities available and the incentive for development. The manager exerts most influence as he selects the employees, assigns work and evaluates performance.

To facilitate illustration, a number of factors which affect both climate and management development effectiveness are discussed below. While it is accepted that these factors generally interact to provide the resultant climate, the author believes that this paper's objectives can best be achieved if a conceptual approach to each factor is presented on an individual basis.

\section{Top-management commitment}

One of the most critical determinants of the attitudes an organization's management holds towards training and development, is the attitude and commitment to training displayed by the organization's 'number one' person (Watson, 1979). ${ }^{2}$

Woodhouse $^{8}$ states that it is not sufficient for top management to commit training and development policies to writing; they (top management) must be known and seen to be involved.

Sewell ${ }^{6}$ concurs and suggests that top-management commitment can be achieved by creating a favourable management development climate and thereafter implementing prescribed management development policies. A favourable climate can be established by providing:

- early opportunity to manage;

- clear goals;

- full responsibility and authority to achieve these goals;

- 'learning' while 'doing' (i.e. on-the-job training);

- exposure to models of managerial competence. By exposing the employee to several managers, the employee can emulate them, assess them and develop his own management style;

- experience with adversity (especially for the highflyer); and

- broad exposure to general management through cross-functional job rotation (where possible), so as to obtain a balanced view of the business as a whole.

Management development policies can be implemented through:

- identifying employee abilities, aptitudes and aspirations;

- careful planning and placement of the employee in a position appropriate to the individual's and the company's needs; 
- growth of competence in a suitable environment until the person is ripe to assume broader accountability;

- training employees to manage their own growth.

Where the Chief Executive Officer (CEO) is attentive to management development, his attitude will pervade the organization from one hierarchical level to the next (Horner). ${ }^{11}$

This is not necessarily the case, says Zeeman. ${ }^{13}$ The pervasive effect of the Chief Executive Officer (CEO) is a function of the size of the organization and the extent to which the CEO is respected. In a very large organization, the CEO is removed from the day-to-day operations. This question of isolation and its effect on organizational climate and management development is extended by Krieken ${ }^{10}$, who submits that isolation from top management can occur through specialization or location (being situated in a secluded or remote area). Isolation produces a negative effect which neither contributes to the success of the organization nor to the esprit de corps or happiness of individuals. Only top management can and should prevent this from occurring.

Top-management commitment to management development was rated number one on the list of important climatic factors by every interviewee. Mackay ${ }^{14}$ believes that one must not be discouraged if it is absent at the outset. There are ways of obtaining it, particularly where bottom-level (i.e. operative) training is good, supervisors and managers are more receptive to experimentation and think more seriously about what their management development needs may be. It is therefore easier to develop managers (and their staff) where they have assisted in preparing their own development plans and where they are committed to seeing them through to completion. This process will then continue from one organizational level to the next - but, from the bottom upwards.

\section{Management style}

The management style of each manager will definitely influence the approach he takes towards management development, according to Phillimore ${ }^{15}$ who also believes that the autocratic (Theory $\mathrm{X}$ ) manager would tend not to be development-oriented.

The Theory Y (participative) manager, would, in the final analysis, tend to get a more productive result. This opinion is echoed by Kellog' who says 'The climate factor is not really as nebulous as the word sometimes seems. It is primarily a matter of the emphasis or priority the manager places on development effort. And it depends, almost wholly, on the encouragement he gives the individual employee'. Favourable interaction leads to development.

Gibson' disagrees. He believes that a manager's style does not affect his basic attitude towards management development. The difference arises in his approach to the selection of those to be developed.

Both Zeeman ${ }^{13}$ and Mackay ${ }^{14}$ state that a manager tends to attract people who are like himself. Good managers attract good people and poor managers, poor people. This is where the blockage in the sysiem can arise. If there is one department in which the manager and his staff are 'all dead from the ankles up', they don't want any development - they don't want to be disturbed. As all departments within the organization are interdependent with one another and all activities must be coordinated if the company is to achieve its overall objectives, a department such as the one just described could inhibit overall effectiveness of the organization, and provide a dampening effect in an otherwise healthy climate.

A manager's style will dictate the extent to which a relationship of mutual trust and understanding can be established with subordinates. This is of particular importance for the successful functioning of any performance and potential appraisal system. Without it, a frank discussion of strengths and weaknesses or realistic career aspirations cannot be achieved. Sewell ${ }^{6}$ states that his experience has shown that:

- unless a manager can establish this kind of relationship with his subordinates, and

- unless he has been satisfactorily trained in the art of appraising,

it is possible that the appraisal system can do more harm than good to the existing climate. $\mathrm{He}$ is aware of instances in which people have resigned because of 'brutally' frank appraisals.

Notwithstanding the fact that a manager's attitude towards delegation is dictated to a large degree by his management style, it is considered of significant importance and is discussed separately below.

\section{Attitude towards delegation}

A manager's attitude towards delegation will affect his attitude towards management development. A manager who has risen from a technical specialization tends to gravitate to that which he knows best - his core skills. Thus, says Phillimore, ${ }^{15}$ a manager who tends continually to move back to the technical tasks of his original discipline, will not allow his subordinates to develop because he will always undertake the more stimulating project himself, leaving the more routine and mundane projects for his subordinates. The result: frustration and a demotivated group of subordinates.

This all-too-common problem can be alleviated, suggests Mackay ${ }^{14}$, who submits that middle and supervisory management will become more effective if they are provided with training in three basic areas:

(i) Coaching skills to develop subordinates. Management must provide the latter with opportunities to perform.

(ii) The manager must know what is expected of him as a manager and what his role as a manager is. Experience has shown that a number of managers lacked knowledge of basic techniques such as planning and scheduling their own work and the work of their subordinates. However, it is important not to push any one style of management.

(iii) Behavioural skills in the area of leadership. A number of decisions in a large organization are made in groups. If the manager contributes to and manages the group constructively, the group could be effective as a developmental tool. 
In addition, situational leadership is important. It is explained by Phillimore ${ }^{15}$ as a concept for which a training technique is used to show individuals what basic management style they adopt - how that style affects (both constructively and destructively) superiors, peers and subordinates under different conditions and in different situations. Managers are then shown how they can go about modifying their style to suit the situation.

\section{Insecurity and resistance to change}

Man is basically a creature of habit. He feels secure in a daily routine, and fears the unknown. In the organizational context, superiors might have cause to feel insecure and become negative if their subordinates attend development programmes and they do not. In these situations, supervisors often feel that subordinates have learned about recently developed theories and practices which they do not yet know. This can be uncomfortable for them (Watson, 1979). ${ }^{2}$

In addition, negative attitudes can develop if those receiving training return to the office and openly discuss ideas and concepts learned while on a programme which supervisors and peers neither underștand nor agree with. One possible solution is to send both superior and subordinate to the same training or development session (Horner). ${ }^{11}$

Woodhouse $^{8}$ feels, however, that if the seminar delegate cannot sell these new ideas to his peers, superiors and subordinates, then he is possibly not the sort of individual that should be attending these programmes and that the selection of delegates is the important factor.

Although selection of participants is important, Krieken ${ }^{10}$ raises the point that the philosophies of the programme could clash with those prevailing in the company. When their newly-learned techniques seem impractical in view of the unsurmountable constraints, delegates may leave the company, seeking other organizations where they believe their talents can be more fruitfully used.

Sewell ${ }^{6}$ suggests a two-point plan of action to overcome this problem: Firstly, external programmes should be cleared by the company both in terms of the reputation of those administering the seminar or workshop, and in terms of the course content. Secondly, participants should be very carefully selected. Before attending any programme, the participant must have a clear selfdevelopment objective. Furthermore a learning contract must be established with his superior so that agreement is reached in principle upon the project he will undertake upon his return to office.

\section{Expectations and feedback}

Feedback has also been suggested as a way of minimizing insecurity and optimizing the return on any development programme (Zeeman). ${ }^{13}$

Horner" , however, points out that too much feedback will raise expectations that cannot be fulfilled. This will in turn lead to frustration and even possibly an increased labour turnover.

The present skills shortage and dearth of management talent makes it imperative that companies retain staff. In order to cope with undue expectations, controlled feedback is needed. The individual employee's career path must be defined in the short to medium term in a clear and unambiguous manner without indicating that the sky is the limit. High-flyers need to be reassured on a regular basis (say at six-monthly intervals). In many instances, career path definition will come from the individual himself (Phillimore). ${ }^{\text {Is }}$

Sewell ${ }^{h}$ submits that a rapidly expanding company need not be overconcerned with raising employee expectations unduly.

The concept of feedback, in a general sense, is well described by Miller and Bainbridge ${ }^{16}$ who say that 'by discussing your performance with your manager, you learn what strengths you have and what areas you need to improve. As people learn new skills and grow personally, they apply what they have learned to their work. Since the company is made up of individuals who have skills and abilities, the effectiveness of the company increases if those skills and abilities improve. If your people do not find ways of personally growing at work, they will do it in other endeavours. Employees are more motivated when they are developing themselves at the same time as they are doing their jobs'.

\section{General attitudes and perceptions}

To a large extent, people's actions are governed by their attitudes. Therefore, when some people are either unwilling or unable to reject publicly the content of a training session, they do so by cutting off the application of what they have learnt. They show their resistance or rejection to the idea by not applying what they have 'learnt' saying 'it's all theory' or 'it won't work here' (Watson).'

Indifference to training is a commonly found constraint. It exists primarily because most people have had no positive experience with training. In addition, says Zeeman ${ }^{13}$, people may receive careful guidance and the necessary developmental opportunities, but they must choose to improve if change is to occur.

Mackay ${ }^{14}$ concurs with this viewpoint. He explains that not all people wish to be developed. Some people are quite content with their present status and position in life. Any efficient organization needs, and has a place for, a limited number of these people. Any attempt to impose development on them leads to frustration and discontentment. A further problem is making sure that people who say they want to be developed, really do. Furthermore, there are those managers who outwardly endorse and support top-management policy on management development, but inwardly do little or nothing to implement this policy.

The challenge posed by negative attitudes held by superiors, peers and subordinates towards newly acquired knowledge and attempts at its application can be a most formidable one. Negative attitudes often give rise to social pressures which can be an extremely strong force in controlling and modifying behaviour. This type of social pressure can completely shut off a person's attempts to apply new ideas, or at least quickly stop him from trying to apply these ideas over an extended period of time (Watson). ${ }^{2}$ If the concepts learned are not reinforced during this period, the 'sleeper effect' will come into play and the individual will gradually forget what he has learnt. 
Peer group pressures need not only have a negative effect, suggests Phillimore. ${ }^{15}$ If most of the members of a group have been on a course, it is likely that group pressure will influence the remaining members to attend the course.

Perceptions, too, play an important part and are often overlooked. Our perceptions of how we are managing others can, and often do, differ from the perceptions of how subordinates believe we are managing them. Also our perceptions of ourselves can be different from the perceptions others have of us.

A model of interpersonal communication processes, known as the Johari Window ${ }^{12}$ (see Figure 1) conceptualizes this phenomenon.

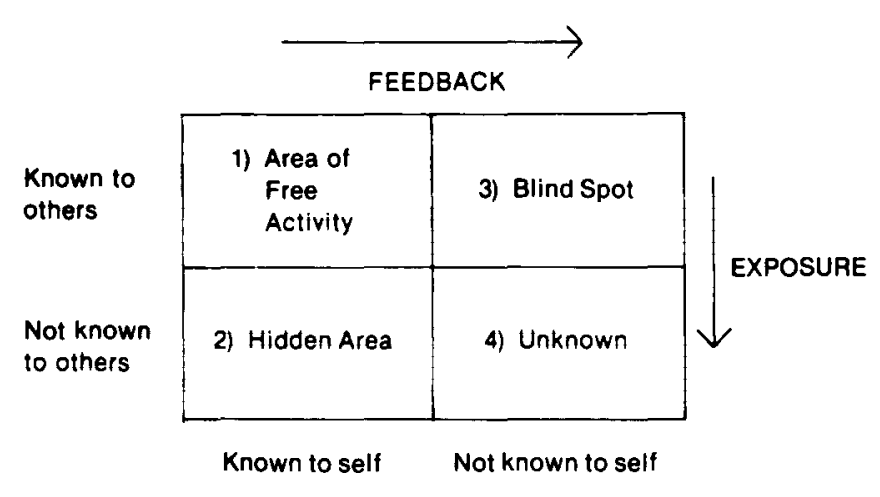

Figure 1 Johari Window on communication processes.

By increasing the area of free activity, interpersonal effectiveness will become more rewarding and effective. This would be achieved through increasing both one's feedback and one's exposure.

\section{Counselling and coaching}

Constructive coaching is a key element in any successful management development system. It facilitates communication and therefore improves organizational climate (Sewell). ${ }^{6}$

Bacchioni ${ }^{9}$ believes that counselling should ideally be used to match the aspirations of the individual with the goals of the company.

Mackay ${ }^{14}$ states that every manager must be given the skill of counselling his subordinate. If the counsellor plays God, communications will break down. If the counsellor and subordinate argue, a negotiating situation will result. This is also undesirable. The role of the counsellor is to assist the individual in thinking through what his needs are and what he should be doing to satisfy those needs. The counsellor should provide input in the form of guidance.

\section{Profit orientation vs management development}

Because most supervisors or managers feel that they have seen very little in the way of clear-cut, well-labelled developmental action on the part of previous or current bosses, their ideas about development - what it is and how it happens - are very sketchy. They tend to think of it in terms of preparing individuals for some imagined future position; and, faced with the choice between today's results or someone else's future five or ten years from now, they unhesitatingly choose today's results.
In an achievement-oriented organization in which line managers are evaluated on profits, there is the possibility that short-term decisions can be taken at the expense of long-term growth.

Bacchioni ${ }^{9}$ suggests that in these circumstances line managers would either refrain from spending their training budgets or would use cheap methods of development in order to add to profit. Because these managers will not carry excess staff, he recommends that a regional or head office budget be available for trainees. As the manager or supervisor is not paying for trainees and the 'bottom-line' is not directly affected, they would be more receptive to development in general.

\section{Organizational pressures}

It is possible that the organizational form is not in harmony with the environment. A highly mechanistic structure is, for example, not suited to a rapidly changing environment. In addition, operations may be strained, either because of poor trading results or excessive expansion. Furthermore, legislative or policy changes could bring pressure to bear on the organization. A legislative or policy change dealing with minorities is a good example. In these circumstances, interpersonal relationships will be strained. The organization climate may be poor and management development systems may be largely ineffective.

\section{Policies affecting management development}

A policy of promoting from within can do much to foster both organization climate and management development effort. Gibson ${ }^{7}$ states, however, that a policy of this nature will be dictated by the size of the company and the rate of growth. Further, a policy of promoting from within should not be an unbreakable law since it promotes inbreeding.

Top management's policy regarding on whom development efforts should be focussed will have a notable effect upon the attitude of employees and the prevailing climate. Negative attitudes may result if a 'Crown Prince' approach is adopted. In terms of this philosophy, a few individuals are identified as showing outstanding promise of growth and all development effort is invested in them. On the other hand, the 'opportunity for all' approach requires a great deal of effort to raise the level of contribution for the total workforce. It should be recognized that not everyone wants to or should want to advance occupationally. If poorly administered, this policy could also result in promoting negative attitudes.

\section{Incentive for development}

Even if the most elaborate management development system is in force and top management is fully committed to the cause, if management development effort is not well rewarded and recognized both in terms of hygiene and motivating factors (in Herzberg's terminology), little attempt will be made to synergize developmental effort by employees.

\section{The effect of a poorly implemented management development system}

According to the work of House ${ }^{17}$, there is ample evidence that management development efforts have by 
no means been universally successful. Some have had no demonstratable or measurable effects, others have been known to cause problems such as:

- lower morale among participants;

- increased managerial turnover owing to dissatisfaction;

- undesirable behaviour by participants; and

- conflict between participants and their superiors.

One of the interviewees ${ }^{18}$ demonstrated this fact by relating his experiences in a company with a bureaucratic structure; a high level of centralized control; and a proliferation of standard policies, methods and procedures. Attempts were made by corporate management at introducing management-by-objectives (MBO) together with a management development system. Although top management were ostensibly committed to the 'new philosophy', six years later, the only result was frustration and increased labour turnover.

Van Rijswyk ${ }^{18}$ ascribes failure to the following factors:

- The climate was not conducive to the change in philosophy which was incongruent with the old, and as management was not trained in the new, the old approach prevailed.

- At corporate level, moves were outwardly made to change, but invariably management had no intention of changing, or relinquishing their power.

- They went through the process mechanically without any real understanding of what they were attempting to achieve. Requests are still, today, made as directives. An extract of a memorandum dated 17 September 1980 is quoted below:

'As you all now this training is costing us a good deal of money, thus we want to maximize our return. With this in mind, I can think of no acceptable excuse (short of death) for you, your managers or sales staff not attending these sessions.

These training sessions will, in no way, resemble your normal sales meetings where you sit and listen to others extol the virtues of their product or department and at which you collect great piles of paper to take back to your office with you, which, unfortunately, is too often forgotten once they are back in the office.'

- Finally, no attempt was made to monitor progress.

From the above it can be seen that:

- A power-motivated organizational climate is not conducive to developmental effort; and

- a poorly implemented management development system can have a negative effect on an existing climate.

\section{Conclusions}

The basic philosophies and opinions of those interviewed have been described above. While most interviewees have personnel/training backgrounds, their contributions should not be seen as providing 'expert' opinion, but rather as a description of how they personally view the importance of organizational climate for management development.

It will have been noted that the opinions of some interviewees are diametrically opposed to others in regard to some of the factors discussed. The reader is therefore asked to draw his own conclusions on which approach should be adopted.

Watson's' approach to management development sums up the author's perceptions of the subject in a brief and concise manner. He states that 'management development is a deliberate process. It will flourish in an organization where top management believes in it, supports it and rewards it. It will flourish under the guidance of able and skilful leaders who are looked upon with respect and who are able to coach, guide and assist other managers in the organization in becoming competent and dedicated to developing their own subordinates'. However, in the final analysis, the employee's commitment to his own development is the overriding factor.

\section{References}

1. DE BETTIGNIES, H.C. 'Management Development: The International Perspective'. In: Taylor, B. \& Lippitt, G.L. (Eds.). Management Development and Training Handbook, McGrawHill, 1975.

2. WATSON, C.E. Management Development Through Training. Addison-Wesley, 1979, pp. 2 - 3.

3. DRUCKER, P.F. Management: Tasks, Responsibilities, Praclices. New York: Harper and Row, 1974.

4. MEE, J.F. 'Perspectives for the Future Manager and His Environment'. Committee for Future Study. Indiana University, Bloomington, Indiana, 1975.

5. KELLOG, M.S. 'Closing the Performance Gap: Results-centred Employee Development'. American Management Association, 1967, p. 9.

6. SEWELL, B., Group Training Manager, Edgars Stores Ltd. Unstructured In-depth Interview, January 8, 1981.

7. GIBSON, E., Assistant Manager, Training and Development, financial institution. Unstructured In-depth Interview, January 6,1981 .

8. WOODHOUSE, B., Group Development and Training Officer, Murray \& Roberts Ltd. Unstructured In-depth Interview, December 18, 1980.

9. BACCHIONI, P., Deputy General Manager, Personnel: Nedbank Ltd. Unstructured In-depth Interview, January 16, 1981.

10. KRIEKEN, J. 'Top Management's Role in Management Development'. In: Taylor, B. \& Lippitt, G.L., (Eds.), Management Development and Training Handbook, McGraw-Hill, 1975.

11. HORNER, J., Personnel Consultant, Beer Division, South African Breweries. Unstructured In-depth Interview, January 15,1981 .

12. HELLRIEGEL, D. \& SLOCUM, J.W. Jr. Management: Conlingency Approaches, 2nd ed. Addison-Wesley, 1978, p. 479.

13. ZEEMAN, A., Training Manager, Van Leer SA (Pty) Led. Unstructured In-depth Interview, December 10, 1980.

14. MACKAY, C., Factory Personnel Manager, AECI Modderfontein. Unstructured In-depth Interview, January 28, 1981.

15. PHILliMORE, D., Divisional Personnel Manager, AngloAmerican Diamond Division. Unstructured In-depth Interview, January 6, 1981

16. MILLER, R.E. \& BAINBRIDGE, S.L. Organization Management. Quarterly publication of Johnson Conhols Inc., March 1979.

17. HOUSE, R.J. Management Development: Design, Evaluation and Implementation. Bureau of Industrial Relations, 1967.

18. VAN RIJSWYK, A. Unstructured In-depth Interview, January 15, 1981 